University of Nebraska - Lincoln

DigitalCommons@University of Nebraska - Lincoln

\title{
The Effects of Tax Policies on Entrepreneurship in Emerging Versus Mature Economies: Do Differences Exist Between Nascent and Established Firms?
}

\author{
Benjamin B. Boozer \\ Jacksonville State University \\ Taleah H. Collum \\ Jacksonville State University, tcollum@jsu.edu
}

Follow this and additional works at: https://digitalcommons.unl.edu/jade

Part of the Econometrics Commons, Growth and Development Commons, International Economics Commons, Political Economy Commons, Public Economics Commons, and the Regional Economics Commons

Boozer, Benjamin B. and Collum, Taleah H., "The Effects of Tax Policies on Entrepreneurship in Emerging Versus Mature Economies: Do Differences Exist Between Nascent and Established Firms?" (2021). Journal for the Advancement of Developing Economies. 48.

https://digitalcommons.unl.edu/jade/48

This Article is brought to you for free and open access by the Institute for the Advancement of Developing Economies at DigitalCommons@University of Nebraska - Lincoln. It has been accepted for inclusion in Journal for the Advancement of Developing Economies by an authorized administrator of DigitalCommons@University of Nebraska - Lincoln. 


\title{
The Effects of Tax Policies on Entrepreneurship in Emerging Versus Mature Economies: Do Differences Exist Between Nascent and Established Firms?
}

\author{
Benjamin B. Boozer Jr., Taleah H. Collum* \\ College of Business and Industry, Jacksonville State University, USA
}

\begin{abstract}
An extensive body of research defines various levels of entrepreneurship and considers emerging trends. This study uses data from Global Entrepreneurship Monitor (GEM) in developing a model that measures the impact of taxes and bureaucracy on entrepreneurship. The analysis considers effects by type of firm - nascent and established - and type of economy-emerging and mature. The aim of the manuscript is to test directional impact of tax policies on entrepreneurial activity. The model utilizes counter and dichotomous variables to measure effects before, during, and after the 2008-2009 Financial Crisis. Tax policies adversely impact both nascent and established firms within an emerging economy but have a positive correlation with nascent firms in a mature economy. The fact that nascent firm development increases after the Financial Crisis suggests that tax policies may offer a foundation of support for those firms that otherwise may be burdensome.
\end{abstract}

Keywords: Entrepreneurship, taxes, firm growth, developing economy, financial crisis *Corresponding author: tcollum@jsu.edu / 850-251-0039

\section{INTRODUCTION}

Entrepreneurship represents a type of business activity that denotes starting and operating a business in making a product, selling a product, producing a service or a combination of the three (Corporate Finance Institute, 2020). Entrepreneurial business activity may be defined in various ways but often includes how a firm is established for tax filing purposes (Bruce \& Mohsin, 2006; Bruce \& Deskins, 2010). Entrepreneurs often choose a tax filing status that minimizes taxation. Choosing a tax filing status is one of the many challenges a firm faces given the complexities of markets and economies in which it operates. Tax policies, as well as other macro and micro policies, may support or inhibit entrepreneurial business activity in nascent and established firms. Specifically, this analysis explores to what extent taxes and bureaucratic policies instituted within an economy affect entrepreneurial activity and development of nascent firms that have recently started or are in early stages of development and established firms that have a history of operations and are otherwise more developed. We consider these firms within two types of economies emerging economy and mature economy.

Countries with emerging economies are defined by several market factors. The most defining factor is rapid economic growth which is measured using Gross Domestic Product (GDP) (Corporate Finance Institute, 2021). An emerging economy will typically grow between six and seven percent while a mature economy experiences growth at a rate less than three percent. Other factors include high productivity levels, increases to the middle class, transition from a closed economy to an open economy, instability and volatility, and attraction of foreign and local 
investment. Emerging economies are somewhere between the "developing" and "developed" or "mature" phase of an economy (Corporate Finance Institute, 2021) which is defined as an economy with a stable population and slowing economic growth (Nasdaq, 2021).

This research takes the idea that the effects of tax policies on entrepreneurship vary depending on the type of firm and the economy in which the firm operates. Nascent firms in an emerging economy would generally be considered the most vulnerable to burdensome tax policy, while established firms in a mature economy would be less affected. Prior literature focuses primarily on the extent that an increase in taxes, and an increase in corporate taxes, more specifically, affects entrepreneurship (Darnehamedani et al., 2018). Results of the directional relationship between tax policy and entrepreneurial activity is typically an inverse correlation, where higher taxes generally impede business development (Bruce \& Deskins, 2010). While less prevalent in the literature, a positive relationship has also been found with progressive tax policies supporting entrepreneurship (Borchers et al., 2016).

The purpose of this research is to examine the impact of taxes and bureaucracy on entrepreneurship. Our research is based on the idea from prior literature that an inverse relationship generally exists between levels of taxes and entrepreneurship (Bruce \& Deskins, 2010). We extend the prior literature by including type of economy (emerging versus mature) to isolate the effect of taxes and bureaucracy. Additionally, we measure differences before, during, and after the 20082009 financial crisis, to control for differences in economic conditions that might impact these relationships. Because tax and other bureaucratic policies can have significant impacts on a business' decisions about capital flows, we believe this study will be of interest to businesses, especially those engaged in entrepreneurial activities. We also believe this study will be of interest to policymakers and other stakeholders from areas competing for these capital flows.

The remainder of the analysis is structured as follows: synthesis of literature review as evidence of support for the model; methodology section of statistical processes to employ and measure outcomes to analyze; results of the output; and examination of the model in extending literature and conclusion.

\section{LITERATURE REVIEW}

The literature on the effects of taxation on entrepreneurship varies widely. Some studies examine data from one country (Borchers et al., 2016; Bruce \& Deskins, 2010; Bruce \& Mohsin, 2006; Cauwenberge et al., 2016; Twesige \& Gasheja, 2019) while others examine the relationship at the country level by looking at one or more countries (Baliamoune-Lutz, 2014; Feyitimi et al., 2016; Folster, 2002). From an entrepreneurship perspective, studies analyze the effects of taxation on different levels of firm development. Some studies focus only on firm entry/nascent firms (Baliamoune-Lutz \& Garello, 2014; Belitski et al., 2016; Chowdhury et al., 2015; Gentry \& Hubbard, 2005; Venancio et al., 2020) while others focus only on established firms (Borchers et al., 2016; Bruce \& Deskins, 2010; Bruce \& Mohsin, 2006; Cauwenberge et al., 2016; Darnehamedini et al., 2018; Feyitimi et al., 2016; Folster, 2002; Twesige \& Gasheja, 2019). Some studies focus on both nascent and established firms (Baliamoune-Lutz, 2014; Bilan et al., 2018; Bruhn \& Loeprick, 2016; Djankov et al., 2010). 


\section{Established Firms}

Darnehamedini et al. (2018) examined 43,223 entrepreneurs from 53 different countries. The study results indicate a negative relationship between corporate taxes (country level data) and innovative entrepreneurial activities and no relationship between personal income taxes (country level data) and entrepreneurial activities. The author explains that this difference occurs because personal income taxes typically allow for deductions for losses while corporate taxes do not, thus, reducing resources incorporated firms must invest in innovative entrepreneurship.

A study conducted by Folster (2002) on Organization for Co-operation and Development (OECD) countries, suggests that there is a strong negative correlation between a firm's tax burden measured as a percentage of GDP and self-employment (measured as a percentage of total employment excluding farming). Feyitimi et al. (2016) conducted a study on the developing economy of Nigeria. They collected data through surveys, interviews, and observations of SMEs (small and medium scale enterprises). They examined the relationship between taxation and SME growth and found a significant relationship between tax incentives (measured by capital allowance) and the growth of SMEs. They also concluded that tax incentives can be used as an effective tool to increase SME growth. Twesige and Gasheja (2019) collected data through surveys of SMEs in Rwanda and found that tax incentives including investment allowance, loss carried forward, tax holiday, wear and tear, and preferential corporate income tax rate are positively and significantly related to SME growth (increase in assets and retained earnings).

Cauwenberge et al. (2016) examined financial accounts for 308 Flemish municipalities and approximately 70,000 firms in those municipalities for 2004-2013. They found that municipal taxation (measured as all taxes a firm is subjected to in one year at the municipality level) has a negative relationship with added value growth but no significant relationship with asset growth or employment growth. They also found that municipal spending has a positive relationship with added value growth and employment growth. Overall, the author concludes that the significance of the relationship between municipal policy (municipal taxation and municipal spending) and firm growth is small and further notes that the limited significance was too small to outweigh the recent financial crisis that had occurred in Belgium.

Similarly, researchers have conducted many studies on state tax policy in the United States. For example, Borchers et al. (2016) found that higher state sales tax rates and higher top marginal CIT (corporate income tax) rates reduce the growth rate of small businesses. They also found a significant and positive relationship between top marginal PIT (personal income tax) rates and small business firm and establishment growth. Additionally, states that have a state inheritance, estate, or gift tax had less small business firm, establishment, and payroll growth. Taking into consideration all the results from the study, the authors concluded that a state's tax policy can significantly impact small business firm, establishment, payroll, and employment growth.

Additionally, a study conducted by Bruce and Deskins (2010) on the 50 United States suggests that state taxes policies, in general, do not significantly impact entrepreneurial activity. However, the authors found that certain state-level taxes such as personal income tax rates; the presence of estate, inheritance, or gift tax; and corporate income tax with a higher weight on the sales factor in the tax apportionment formula do have a negative effect on entrepreneurial activity. The authors 
also found that more progressive income tax structures and more aggressive corporate income taxes through a combined reporting requirement slightly increased entrepreneurial activity. The authors measured entrepreneurship in two ways: federal tax returns from each state that included a schedule $\mathrm{C}$ (excluding farm workers) as a percentage of all federal individual tax returns filed for that state and the number of sole proprietors from each state as a percentage of all workers (excluding farmers).

Bruce and Mohsin (2006) analyzed how tax policies affect entrepreneurship in the United States using time series data. They used four measures for entrepreneurship: (1) the percentage of individual income tax returns that report income from a small business or farm (2) adds tax returns for partnerships and small business corporations with income to number 1 (3) the percentage of total non-agricultural work force that are age 16 or older and are self-employed and (4) adds to number 3 by adding workers in the agricultural sector. They measured taxes as the highest tax rates from personal income, payroll, capital gains, and corporate income. The authors found small but significant effects between the corporate income tax rate and all four measures of entrepreneurship and between payroll tax rate and the fourth measure (as noted above) of entrepreneurship, indicating that self-employment can be affected by tax policies.

\section{Nascent Firms}

Gentry and Hubbard (2005) analyzed the relationship between tax policy and firm entry. The results of this study indicate that the level of the marginal tax rate is inversely related to entrepreneurial entry. Additionally, they found that the progressivity of the tax also is significantly and negatively related to entrepreneurial entry for some groups of households.

Venancio et al. (2020) conducted a study in Portugal on start-ups located in inland municipalities and suggested that tax reform (reduced corporate tax rate) increases the number of firms entering the market and the number of jobs created by new firms. They measured entry rate as the number of new entrants relative to the number of existing firms at the beginning of each year. New firm job creation rates are calculated as the number of jobs created by start-ups relative to the total workforce at the beginning of the year.

Another study, conducted by Belitski et al. (2016), used data from 72 countries for the years 20052011 to examine the relationship between taxes and corruption and firm entry. The authors found that higher corporate tax rates consistently discourage firm entry. They defined firm entry as the number of new limited liability (LLCs) established per 1000 people in a country.

Chowdhury et al. (2015) conducted a study on 155 nascent firms in 48 countries. They measured entrepreneurship using the variable "nascent international entrepreneurship" from the GEM database. This variable is the aggregated measure of international entrepreneurial activity, and it is self-reported by entrepreneurs. The independent variables include two tax variables as their independent variables. First, they use corporate tax which is measured as the percentage of taxes on profits paid by the business as a percentage of commercial profits. They also use a variable called "indirect tax" which includes value added tax and sales tax. They analyzed the effects of corruption when combined with these two tax variables. The authors found that corporate taxes are not a major deterrent for international entrepreneurship when corruption is low. 
Baliamoune-Lutz and Garello (2014) used macro-level panel data from a group of European countries that have gone through a financial crisis in recent years to examine the effects of tax rates (average and marginal personal tax rates) and tax progressivity on nascent entrepreneurship. They measure nascent entrepreneurship with the variable "GEM-nascent" from the GEM (Global Entrepreneurship Monitor) database. The results indicate that tax progressivity has a significant negative effect on entrepreneurship among those with higher-than-average incomes. They also found a significant inverse relationship between average and marginal tax rates and entrepreneurship.

\section{Nascent Firms and Established Firms}

Djankov et al. (2010) examined data on mid-size domestic firms in 85 different countries and found that effective corporate tax rates have a significant impact on investment and entrepreneurship. They measure investment using two variables: gross fixed capital formation and foreign direct investment (FDI). Each of these variables was calculated as a percentage of GDP. Entrepreneurship was also measured using two variables: the number of business establishments and the rate of new business registration.

Baliamoune-Lutz (2014) examined the relationship between 1) taxes and nascent entrepreneurship and 2) taxes and established business ownership in 23 OECD countries using data from 20002009. The only significant result found was a negative relationship between tax progressivity and nascent firms (the percent of the country's population that is 18-64 and are nascent entrepreneurs). There was no significant relationship between tax progressivity and established firms (the percent of the country's population who are currently an owner-manager of an established business). Additionally, changes in marginal and average tax rates were not significantly related to either type of entrepreneurship.

Another study, conducted by Bilan et al. (2018), examined Eastern European and Baltic countries from 2006-2017 for a relationship between tax competition and entrepreneurship. The authors found that higher levels of absolute tax rates, higher tax burdens, time allowed to pay taxes, and the number of tax payments for enterprises restrain entrepreneurial activity in some way.

Bruhn and Loeprick (2016) conducted a study on micro-businesses and small business in the country of Georgia in 2010. The results of the study suggest that tax reform that includes preferential tax regimes has a positive impact on newly registered firms in the year the reform was implemented but not in subsequent years. This study also suggests reduced tax compliance among small taxpayers (revenues between GEL 30,000 and GEL 100,000) for multiple years after the reform was implemented and one year after it was implemented for micro-businesses (revenues below GEL 30,000).

In summary, levels of entrepreneurship have been defined in various ways in previous literature on taxation and entrepreneurship. Firm entry or nascent firm has been defined using the variable "nascent international entrepreneurship" (Baliamoune-Lutz \& Garello, 2014; Chowdhury et al., 2015) from the Global Enterprise Monitoring (GEM) database. Other authors used the number of new limited liability companies established per 1000 people in a country (Belitski et al., 2016), the number of new entrants relative to the number of existing firms at the beginning of each year or 
the number of jobs created by start-ups relative to the total workforce at the beginning of the year (Venancio et al., 2020), the number of new business registrations (Bruhn \& Loeprick, 2016; Djankov et al., 2010), or the percentage of the population ages 18-64 that are nascent entrepreneurs (Baliamoune-Lutz \& Garello, 2014). For established firms, entrepreneurship has been measured in several different ways using tax return data such as firms that fill out a schedule $\mathrm{C}$, non-farm workers that are sole proprietors (Bruce \& Deskins, 2010), the percentage of personal tax returns with income from a small business or farm, tax returns for partnerships or small business corporations, and several others (Bruce \& Mohsin, 2006). Entrepreneurship for established firms has also been measured using variables from other data sources. These variables include innovative entrepreneurial activities from the GEM database (Darnehamedani et al., 2018), increases in assets (Cauwenberge et al., 2016; Twesige \& Gasheja, 2019), increases in retained earnings (Twesige \& Gasheja, 2019), added value growth (Cauwenberge et al., 2016), employment growth (Borchers et al., 2016; Cauwenberge et al., 2016), and payroll growth (Borchers et al., 2016).

Additionally, taxation has been measured in multiple ways in the literature on taxation and entrepreneurship. Most commonly, authors have analyzed how corporate tax rates affect entrepreneurship (Borchers et al., 2016; Bruce \& Deskins, 2010; Bruce \& Mohsin, 2006; Darnehamedani et al., 2018; Djankov et al., 2010; Venancio et al., 2020). Each of these studies found a significant negative relationship between the two variables. Other studies analyzed the impact of average and marginal personal income tax rates on nascent firms. Baliamoune-Lutz and Garello (2014) found a negative relationship, Borchers et al. (2016) found a positive relationship, and Baliamoune-Lutz (2014) found no relationship. Additionally, Bruce and Deskins (2010) found an inverse relationship between higher individual income tax rates and entrepreneurial activity. Other authors examined the effects of tax progressivity on nascent firms and/or established firms and the effects of tax incentives on firm growth. For example, Baliamounce-Lutz (2014) and Baliamounce-Lutz and Garello (2014) both found an inverse relationship between tax progressivity and nascent entrepreneurship. They did not find a significant relationship between tax progressivity and established firms. Additionally, Feyitimi et al. (2016) and Twesige and Gasheja (2019) found that tax incentives are positively related to firm growth. Other tax variables examined in the literature include a firm's tax burden as a percentage of GDP (Folster, 2002), all taxes a firm is subjected to in a certain municipality in a year (Cauwenberge et al., 2016), sales tax rate (Borchers et al., 2016), state inheritance and estate and gift tax rates (Borchers et al., 2016; Bruce \& Deskins, 2010), payroll tax, and capital gains tax. All these variables were negatively related to entrepreneurship as defined in each individual study.

Although most studies suggest that increased taxes hinder entrepreneurship at all levels, some studies find differing results. Additionally, this relationship has not been examined in the context of the type of economy in which a firm operates. Our research provides additional evidence on the relationship between taxes and entrepreneurship as well as the relationship in the context of the type of economy in which a firm operates.

\section{METHODOLOGY}

Participants 
The type of research for this analysis seeks to develop predictions of the effect of taxes and bureaucracy within an economy as a causal factor for entrepreneurial activity. Deductive logic is employed in testing a hypothesis based on the findings of our model. Secondary research data were obtained from GEM and expressed in the quantitative model. Descriptive statistics are provided along with t-test variance of mean differences. By considering the variables, the content validity of the model is acceptable in testing the relationship between taxes and bureaucracy and levels of nascent or established entrepreneurship. Gaps in the literature are addressed by using this approach, where type of firm and type of economy are considered collectively rather than measured individually.

Survey results from GEM identify percent of population aged 18-64 who have recently started a business or are an owner-manager of a firm that has paid wages and salaries or received payments to owners for more than 42 months. Entrepreneurs that are actively starting a new business or have been in business and paying wages for at least 3 months but no more than 42 months would be classified as a nascent firm. Entrepreneurs that have been in business and paying wages for at least 42 months would be considered an established firm (Bosma et al., 2020). Years measured for the analysis are 2001-2019, inclusive ${ }^{1}$. For the three countries identified for each type of economy, there are 60 observations for each economy type.

This research uses taxes and bureaucracy as the primary independent variable in measuring entrepreneurship by type of economy and development level of entrepreneurship. According to GEM, taxes and bureaucracy represent the basic level of governmental support through tax incentives and less burdensome regulation by entities within each country. Additional variables are not employed in the model in that our objective is to focus on impact before, during, and after a cataclysmic economic event. We control for the inclusion of these variables via coefficient of variation explanatory power.

\section{Design}

The analysis also employs dichotomous and counter variables within the equation to isolate time value effects individually attributable to the independent variable measured to explain the effects of economic disruption. We use the transitional year of 2009 to isolate changes before, during, and after the Financial Crisis. The BEFORE variable is coded to count sequentially each year of the analysis. The CHANGE variable is dichotomous, with years before and including the crisis year coded a zero and one for each succeeding year. The AFTER variable captures changes after the financial crisis. The variable is coded zero for each year before and including the financial crisis and counts one, two, three, etc. for each year after the event.

Each variable estimates changes in entrepreneurship before, during, and after the crisis event. To the extent that each variable is coded to control for unexpected effects in estimating this measure, the model indicates directional impacts in entrepreneurial activity, respectively.

This methodology mirrors a model developed by Boozer et al. (2016), Kellough (1990), Landry et al. (2012), Miller and Pierce (1997); and Netter et al. (1990). Directional changes are imperative

\footnotetext{
${ }^{1}$ For years when data were missing for selected countries, smoothing average of existing data was utilized in deriving those values.
} 
to this measure, with timing of the change before, during, or after a change in economic conditions foreshadowing the role of the economy on entrepreneurship in this model. This model utilizes stepwise regression. Based on the statistical significance of each, variables are added to the model with the last iteration representing the best fit of the data along a regression line.

\section{Procedure}

Two dependent variables are identified in the model - nascent firms and established firms - by level of entrepreneurship. Each dependent variable is analyzed for each type of economy. A t-test considers differences in means for each type of firm within each economy and multiple regression measures multivariate effects. Results indicate that significant differences in entrepreneurship exist between type of firm - Nascent and Established - when the economy was mature, but the same relationship was not found in an emerging economy. An ordinary least squares estimate is developed to measure the effects of policies pertaining to taxes and bureaucracy on firms by level of entrepreneurship and considers to what extend these effects oscillate before, during, and after the identified economic calamity. Level of entrepreneurship is considered independently with nascent firms and established firms substituted in the following regression equation. Further, each change variable - BEFORE, CHANGE, and AFTER - is measured individually with taxes and bureaucracy in the equation.

Level of Entrepreneurship $=\alpha+\beta 1($ Taxes and Bureaucracy $)+\beta 2($ BEFORE $)+\beta 3(\mathrm{CHANGE})+$ $\beta 4($ AFTER)

Level of entrepreneurship is measured as the number of nascent and established firms within an emerging and mature economy and is derived from GEM survey results. Taxes and bureaucracy measure tax and regulatory burden on business as a result of policies within the countries identified. Level of entrepreneurship and taxes and bureaucracy are measured as percent of population. The three counter variables - BEFORE, CHANGE, and AFTER - are ordinal level data. Ordinary Least Squares regression is utilized in measuring effects of predictor variables on changes in type of entrepreneurship.

The research question for the model tests the following three areas: (1) Do taxes and bureaucracy play a role in level of entrepreneurial development; (2) to what extent is type of economy a factor in entrepreneurship; and (3) does entrepreneurship vary in relation to economic conditions.

In using three counter variables the possibility of autocorrelation exists, which would violate the premise of OLS regression in predicting output (Miller \& Pierce, 1997). Durbin and Watson (1950) developed a statistic to identify the presence of autocorrelation with usual ranges from 1.5 to 2.5 as relatively normal. Field (2009) states that values higher than 3.0 and lower than 1.0 are cause for concern. Durbin-Watson measure should be in an acceptable range or the data transformed by implementing a Cochrane and Orcutt process (Cochrane \& Orcutt, 1949).

Emerging economies are somewhere between the "developing" and "developed" or "mature" phase of an economy (Corporate Finance Institute, 2021) which is defined as an economy with a stable population and slowing economic growth (Nasdaq, 2021). Countries selected are based on larger Gross Domestic Product. Emerging economies are identified as Brazil, India, and South 
Korea $^{2}$. Mature economies are identified as Germany, United Kingdom, and United States. Data are grouped as a panel study analysis by economy for each type of firm.

In the following results section, descriptive statistics present $t$-test results of mean differences in type of firm for each economy. Using the software Statistical Package for the Social Sciences (SPSS), a multivariate statistical output for the model is presented for emerging economy and for mature economy.

\section{RESULTS AND DISCUSSION}

\section{Descriptive Statistics and Comparison of Means}

In an examination of mean differences in entrepreneurship for nascent and established firms in an emerging economy, values of the observed differences are small. Mean value for nascent is only slightly higher than established at 12.5467 versus 11.1082 . Variance for each type of firm - nascent and established - is almost identical, with a higher value for established firms in an emerging economy as opposed to much higher values for nascent firms in a mature economy. The p-value value for the two tailed test is $\mathrm{p}=0.0449$, which is the probability that the value of the $\mathrm{t}$ statistic (2.0284) is larger than the value of the critical $t$ value (1.9814). Each value is measured in terms of absolute value. Based on a two-sample t-Test with unequal variances, hypothesis testing is as follows:

$\mathrm{H}_{0}$ : No significant difference in the means of each sample exists.

$\mathrm{H}_{1}$ : Significant difference in the means of each sample exists.

With the p-value less than alpha of 0.05 , reject $\mathrm{H}_{0}$ that there is no significant difference in the means of each sample. These findings are expressed in Table 1 Emerging Economy Entrepreneur Two-Sample t-test.

Table 1: Emerging Economy Entrepreneur Two-Sample t-test with Unequal Variances

\begin{tabular}{|l|c|c|}
\hline & Nascent & Established \\
\hline Mean & 12.5467 & 11.1082 \\
\hline Variance & 14.2511 & 14.4154 \\
\hline Observations & 57 & 57 \\
\hline Hypothesized Mean Difference & 0 & \\
\hline Degrees of freedom & 112 & \\
\hline $\mathrm{t}$ statistic & 2.0284 & \\
\hline $\mathrm{P}(\mathrm{T}<=\mathrm{t})$ two-tail & 0.0449 & \\
\hline $\mathrm{t}$ Critical two-tail & 1.9814 & \\
\hline
\end{tabular}

In an examination of mean differences in entrepreneurship for nascent versus established firms in a mature economy, results are much more extreme than in emerging economy. Nascent firms

\footnotetext{
${ }^{2}$ United Nations changed the designation status of South Korea from a developing economy to a developed economy in July 2021. With this model measuring years 2001-2019, inclusive, we classify the status as developing to be consistent with its designation during the period of analysis.
} 
produce higher mean values relative to established firms, but with a much higher degree of variance. For nascent firms, variance in mean value is 11.2621 and 2.3109 for established firms.

Using a two tailed test, $p$-value equal to 0.0009 is less than alpha of 0.05 ; reject null hypothesis that no significant difference in means exists. The $\mathrm{p}$-value indicates the probability that the $\mathrm{t}$ statistic absolute value (4.1198) is larger than the absolute value of the critical t value (1.9908). This implies that a significant difference in the mean value of nascent and established firms exists in a mature economy. See Table 2 Mature Economy Entrepreneur Two-Sample t-test.

Table 2: Mature Economy Entrepreneur Two-Sample t-test with Unequal Variances

\begin{tabular}{|l|c|c|}
\hline & Nascent & Established \\
\hline Mean & 8.0105 & 6.0002 \\
\hline Variance & 11.2621 & 2.3109 \\
\hline Observations & 57 & 57 \\
\hline Mean Difference & 0 & \\
\hline Degrees of freedom & 78 & \\
\hline t statistic & 4.1198 & \\
\hline $\mathrm{P}(\mathrm{T}<=\mathrm{t})$ two-tail & 0.00009 & \\
\hline $\mathrm{t}$ Critical two-tail & 1.9908 & \\
\hline
\end{tabular}

Model Output

The statistical output of the model used in measuring variable effect by type of firm and economy is presented as results within Table 3 and Table 4. Table 3 identifies the effects of taxes and bureaucracy on nascent and established firms in an emerging economy. Table 4 considers the effects of taxes and bureaucracy on nascent and established firms in a mature economy. The model encompasses years 2001-2019 and measures statistical significance of variable effect before, during, and after 2009, the transitional year of the financial crisis.

Variables with statistical significance are listed; otherwise, the variable is omitted in results presentation. Output is categorized for the independent variables, including each dichotomous and counter variable. Each performance variable is entered individually, along with the counter variables. To find the group of variables that approximate the regression line for $\mathrm{R}$ square, variables are removed sequentially. Emerging economy and mature economy are analyzed, respectively. Higher levels of taxes and bureaucracy in an emerging economy produce lower levels of nascent firm development. This association diverges along a continuum for the period studied in relation to counter and dichotomous variables.

In an emerging economy nascent firm development was declining before the change in economic conditions but increasing after the crisis ended; no statistical relationship existed during the crisis. Taxes and bureaucracy and AFTER are significant at a $\mathrm{p}<.001$. BEFORE is significant at a $\mathrm{p}=$ .007 . The model explains almost 50 percent of nascent firm development in an emerging economy with an R-square of 0.497. Durbin-Watson is in an acceptable range according to Field (2009).

Results for established firms in an emerging economy also find an inverse relationship between higher levels of taxes and bureaucracy and firm development; however, the directional impact of 
this association is not as strong as the findings for nascent firms, and neither is the level of statistical significance $(\mathrm{p}=.001)$. Established firm development in an emerging economy was increasing prior to the financial crisis but changes concurrent to and post financial crisis are not explained by this analysis. The Durbin-Watson value does not indicate autocorrelation. The model explains almost 20 percent of established firm development in an emerging economy with an Rsquare of 0.192. Table 3 Emerging Economy summarized these results.

Table 3: Emerging Economy (Nascent and Established Firms 2001-2019)

\begin{tabular}{|l|c|c|c|c|c|}
\hline \multicolumn{1}{|c|}{ Nascent Firm } & & & & & \\
\hline \multicolumn{1}{|c|}{ Variable } & Coefficient & t-statistic & $\mathrm{p}$-value & Durbin-Watson & R-square \\
\hline Constant & & 13.409 & $\mathrm{p}<.001$ & 2.201 & 0.497 \\
\hline Taxes and Bureaucracy & -.623 & -6.408 & $\mathrm{p}<.001$ & & \\
\hline AFTER & 1.120 & 3.977 & $\mathrm{p}<.001$ & & \\
\hline BEFORE & -.790 & -2.800 & .007 & & \\
\hline
\end{tabular}

\begin{tabular}{|l|c|c|c|c|c|}
\hline \multicolumn{1}{|c|}{ Established Firm } & & & & & \\
\hline \multicolumn{1}{|c|}{ Variable } & Coefficient & t-statistic & $\mathrm{p}$-value & Durbin-Watson & R-square \\
\hline Constant & & 7.743 & $\mathrm{p}<.001$ & 2.108 & 0.192 \\
\hline Taxes and Bureaucracy & -.416 & -3.377 & .001 & & \\
\hline BEFORE & .330 & 2.682 & .010 & & \\
\hline
\end{tabular}

In a mature economy, nascent firm development is positively impacted by higher levels of taxes and bureaucracy. This is paradoxical to the effects observed for taxes and bureaucracy in an emerging economy. The strength of the directional association and the level of statistical significance in measuring the association is not as robust for mature economy, however, in comparison to emerging economy. Nascent firm development was not a predictor in the model before or during economic collapse but expands after crisis conditions end. The model explains 14.2 percent of variability around the mean. Durbin-Watson is higher than 2.0, suggesting some degree of autocorrelation, but still within an acceptable range.

Taxes and bureaucracy is not a predictor of established firm entrepreneurship in a mature economy. Established firms were found to be expanding in a mature economy before the financial crisis with a strong, positive directional impact. An association was not produced during and after the crisis. Durbin-Watson does not indicate autocorrelation and the model explains 33.8 percent of variation from the dependent variable. See Table 4 Mature Economy for illustration.

Table 4: Mature Economy (Nascent and Established Firms 2001-2019)

\begin{tabular}{|c|c|c|c|c|c|}
\hline Table 4 Mature Economy & & & & & \\
\hline Nascent Firm & & & & & \\
\hline Variable & Coefficient & t-statistic & p-value & $\begin{array}{c}\text { Durbin- } \\
\text { Watson }\end{array}$ & R-square \\
\hline Constant & & .149 & .882 & 2.837 & 0.142 \\
\hline Taxes and Bureaucracy & .253 & 2.028 & .047 & & \\
\hline
\end{tabular}




\begin{tabular}{|l|c|c|c|c|c|}
\hline AFTER & .300 & 2.408 & .020 & & \\
\hline \multicolumn{7}{|c|}{ Established Firm } & & & & & \\
\hline \multicolumn{1}{|c|}{ Variable } & Coefficient & t-statistic & p-value & $\begin{array}{c}\text { Durbin- } \\
\text { Watson }\end{array}$ & R-square \\
\hline Constant & & 12.824 & $\mathrm{P}<.001$ & 2.514 & 0.338 \\
\hline BEFORE & .592 & 5.445 & $\mathrm{P}<.001$ & & \\
\hline
\end{tabular}

\section{EXAMINATION AND CONCLUSION}

The results of the analysis produced several interesting effects in addressing the research question for this model. The research question for the model tests the following three areas: (1) Do taxes and bureaucracy play a role in level of entrepreneurial development; (2) to what extent is type of economy a factor in entrepreneurship; and (3) does entrepreneurship vary in relation to economic conditions.

Taxes and bureaucracy indeed affect entrepreneurial development, but impact varies, nevertheless, by type of economy. Higher levels of taxes and bureaucracy appear to stymie both nascent and established firm development in an emerging economy but promote nascent firm development in a mature economy. These findings suggest that the burdensome impact of higher tax levels and regulatory compliance may not be as much of a factor by type of firm as by type of economy. Nascent firms in an emerging economy, perhaps the most perilous scenario for type of firm and type of economy, ironically appear to develop more quickly after an economic calamity even though performance was waning in the years prior. Established firms appear to be less affected by economic changes, although concurrent and post associations are not explained by the model.

Although GEM data has been used in prior literature to measure entrepreneurship, none of the prior studies used the variable "taxes and bureaucracy" to examine the relationship between taxes and entrepreneurship (Baliamoune-Lutz \& Garello, 2014; Chowdhury et al., 2015). Additionally, those articles that used GEM data to measure entrepreneurship did not use the data to measure entrepreneurship as nascent versus mature firms. Instead, some studies used the variables "nascent international entrepreneurship", "GEM-nascent", and "entrepreneurial activities" to examine taxes and possible burden on nascent or established entities (Baliamoune-Lutz \& Garello, 2014; Chowdhury et al., 2015). However, some studies using other data sources to measure entrepreneurship, used a dichotomous variable-"nascent versus established firms" (BaliamouneLutz, 2014) or a variable representing entrepreneurship at various stages of firm development (Bilan et al., 2018; Bruhn \& Loeprick, 2016; Djankov et al., 2010). Additionally, none of the studies analyzing the relationship between taxes and entrepreneurship compared mature versus emerging economies.

The results of this analysis extend the literature by quantifying that while taxes and bureaucracy are negative predictors of entrepreneurship (Borchers et al., 2016; Cauwenberge et al., 2016; and Gentry and Hubbard, 2005), the relationship is not unanimous. Our findings indicate a positive relationship between higher taxes and nascent firm development in a mature economy. Although findings by Twesige and Gasheja (2019) support these results when considering conditions in the country of Rwanda, we contend that the inclusion of multiple countries strengthens the model. 
Prior literature on entrepreneurship and taxes does not include any studies that extend through a change period such as the 2008 financial crisis. However, Lutz and Garello (2014) utilized panel data to consider effects of tax rates (average and marginal personal tax rates) at the macro level and the progressivity of tax policies as a function of nascent entrepreneurship in a large group of European countries that had recently gone through a financial crisis. The research found an inverse relationship between tax progressivity and nascent entrepreneurship. They did not find a significant relationship between tax progressivity and established firms. These findings are inconsistent with the results of this paper and suggest that nascent entrepreneurship is affected differently by taxation in a mature economy, where tax policies and regulatory authority may positively impact the ability of a nascent firm to emerge within established parameters.

\section{REFERENCES}

Baliamoune-Lutz, M. (2014). Taxes and entrepreneurship in OECD countries. Contemporary Economic Policy, 369-380.

Baliamoune-Lutz, M., \& Garello, P. (2014). Tax structure and entrepreneurship. Small Business Economics, 165-190.

Belitski, M., Chowdhurry, F., \& Desai, S. (2016). Taxes, corruption, and entry. Small Business Economics, 201-216.

Bilan, Y., Lyeonov, S., Vasylieva, T., \& Samusevych, Y. (2018). Does tax competition for capital define entrepreneurship trends in Eastern Europe? (27).

Boozer, B. B., Staples, J. A., Lowe, S. K., \& and Landry, R. J. (2016). U.S. corporate pension expense and the 2007-2009 financial crisis: An interrupted time series analysis. International Journal of Business and Finance Research, 10(3), 29-38.

Borchers, E., Deskins, J., \& Ross, A. (2016). Can state tax policies be used to grow small and large businesses? Contemporary Economic Policy, 34(2), 312-335.

Bosma, N., Hill, S., Ionescu-Somers, A., Kelley, D., Levie, J., \& Tarnawa, A. (2020). Global entrepreneurship monitor (GEM) 2019/2020 global report. London: Global Entrepreneurship Research Association.

Bruce, D., \& Deskins, J. (2010). Can state tax policies be used to promote entrepreneurial activity? Small Business Economics.

Bruce, D., \& Mohsin, M. (2006). Tax policy and entrepreneurship: new time series data. Small Business Economics, 26, 409-425.

Bruhn, M., \& Loeprick, J. (2016). Small busiess tax policy and informality: Evidence from Georgia. International Tax and Public Finance, 23, 834-853.

Cauwenberge, P. V., Beyne, P., \& Bauwhede, H. V. (2016). An empirical investigation of the influence of municipal fiscal policy on firm growth. Environment and Planning $C$ : Government and Policy, 34(8), 1825-1842.

Chowdhury, F., Audretch, D. B., \& Belitski, M. (2015). Does corruption matter for international entrepreneurship? International Entrepreneurship and Management Journal, 11, 959980.

Cochrane, D., \& Orcutt, G. H. (1949). Application of least squares regression to relationships containing autocorrelated error terms. Journal of the American Statistical Association, 44, 32-61.

Corporate Finance Institute. (2020, May 29). What is an entrepreneur? https://corporatefinanceinstitute.com/resources/knowledge/other/entrepreneur/. 
Corporate Finance Institute. (2021, January 28). Emerging market economy. https://corporatefinanceinstitute.com/resources/knowledge/economics/emerging-marketeconomy/.

Darnehamedani, P., Block, J. H., Hessels, J., \& Simonyan, A. (2018). Taxes, start-up costs, and innovative entrepreneurship. Small Business Economics, 51, 355-369.

Djankov, S., Ganser, T., McLiesh, C., Ramalho, R., \& Shleifer, A. (2010). The effect of corporate taxes on investment. American Economic Journal, 31-64.

Durbin, J., \& Watson, G. S. (1950). Testing for serial correlation in least squares regression. I. Biometrika, 37, 409-428.

Feyitimi, O., Temitope, O. A., Akeem, L. B., \& Oladele, O. S. (2016). Tax incentives and the growth of small and medium scale enterprises in developing economy-The nigerian experience. European Journal of Research and Reflection In Management Sciences, 4(2), 24-42.

Field, A. (2009). Discovering statistics using SPSS: and sex and drugs and rock ' $n$ ' roll (3rd ed.). London: Sage.

Folster, S. (2002). Do lower taxes stimulate self-employment? Small Business Economics, 19(2), 135.

Gentry, W. M., \& Hubbard, R. G. (2005). "Success taxes," entrepreneurial entry, and innovation. Innovation, Piolicy, and the Economy, 87-108.

Kellough, J. E. (1990). Federal agencies and affirmative action for blacks and women. Social Science Quarterly, 71(1), 83-91.

Landry, R. J., Boozer, B. B., \& Lowe, S. K. (2012). Measurement of homestead exemption utilizing home values. Journal of International Finance Studies, 12(3), 84-93.

Miller, D. E., \& Pierce, P. (1997). Lotteries for education: Windfall or hoax? State and Local Government Review, 29(1), 34-42.

Nasdaq. (2021, March 18). Mature economy. https:/www.nasdaq.com/glossary/m/matureeconomy.

Netter, J., Wasserman, W., \& Kutner, N. (1990). Applied linear statistical models (3rd ed.). Burr-Ridge, Illinois: Richard D. Irwin, Inc.

Twesige, D., \& Gasheja, F. (2019). Effect of tax incentives on the growth of small and mediumsized enterprises (SMEs) in Rwanda: A case study of SMEs in Nyarugenge District. Journal of Accounting and Taxation, 11(5), 89-98.

Venancio, A., Barros, V., \& Raposo, C. (2020). Corporate taxes and high quality entrepreneurship. Small Business Economics. 